\title{
Edukacja literacka wobec wyzwań współczesności - próba diagnozy i propozycje rozwiązań
}

\author{
Literary education facing the challenges of the contemporary world - \\ an attempt at a diagnosis and suggestions of solutions
}

\begin{abstract}
In his article, Maciej Michalski discusses some of the challenges of literary education caused by the pandemic and other contemporary crises (social, environmental, and cognitive). He argues that it is necessary to reduce the growing gap between the content of school education and the problems of the contemporary world. Michalski submits that more emphasis should be put on developing in students attitudes based on empathy, understanding, tolerance, and resilience, which will help them to cope with anxieties and the challenges of the contemporary world. He argues that it is crucial to abandon the text-centered perspective, to use a wider range of non-literary texts, and to show that interpretation can be conceived also as a type of social practice.
\end{abstract}

Keywords: literary education, pandemic, interpretation, school, anxiety, resilience

Jak dramatem II wojny światowej i totalitaryzmów poruszyć uczniów w czasie, kiedy przeżywają oni silny lęk związany ze zmianami klimatu i z prawdopodobną zagładą planety? Jak skłonić młodzież do zachwytów nad sceną polowania w Panu Tadeuszu, skoro tak dużo wiemy o cierpieniach zwierząt? I dalej: jak przedstawiać sarmackie życie w dworku szlacheckim czy dylematy patriotyczne - doświadczenia wąskiej grupy społeczeństwa - skoro przodkowie większości z nas należeli do innych niż opisywana w literaturze warstw społecznych i zajęci byli codziennością oraz przetrwaniem z dnia na dzień? Czy można odwoływać się do wizji wspólnoty i wspólnej historii, gdy obserwujemy głębokie podziały społeczne, światopoglądowe, kulturowe? Jak 
analizować metaforykę barokową w sytuacji, kiedy język wokół nas służy mowie nienawiści?

A przede wszystkim: jak po pandemii, która wstrząsnęła nami - naszą teraźniejszością i przyszłością — uprawiać edukację polonistyczną, w znacznej mierze opierającą się dziś na poznawaniu tradycji i historii literatury oraz zdobywaniu wiedzy o języku?

„Świat umiera, a my nawet tego nie zauważamy” - mówiła Olga Tokarczuk w swojej mowie noblowskiej ${ }^{1}$. „Coś jest ze światem nie tak. To poczucie, zarezerwowane kiedyś tylko dla neurotycznych poetów, dziś staje się epidemią nieokreśloności, sączącym się zewsząd niepokojem"2. Nawet jeśli uznać te słowa za zbyt dramatyczne i emocjonalne, to trudno zaprzeczyć, że kumulacja różnych kryzysów współczesności — szczególnie w perspektywie pandemii wpływa na świadomość zbiorową i skłonić nas powinna do głębokiej refleksji nad edukacją.

Punktem wyjścia moich rozważań i zarazem przedstawionej próby diagnozy edukacji w dobie pandemii jest silne przekonanie, że dzisiejsza dydaktyka, w tym polonistyczna, niebezpiecznie mocno i coraz bardziej oderwana jest od rzeczywistości i problemów współczesnych ludzi, a to wystawia na próbę naszą (wszystkich dorosłych, a dydaktyków w szczególności) wiarygodność. Podejrzewam, że dziś edukacja szkolna traktowana jest przez uczniów jako swoista gra, w której trzeba zdobywać kolejne „levele”, aby osiągnąć narzucane młodym (bo niekoniecznie naprawdę przez nich pożądane) cele. Można to też ująć bardziej radykalnie — określić jako pewną formę przemocy symbolicznej ${ }^{3}$ : narzucamy młodym określony kod zbudowany z przestarzałych znaków i jeszcze bardziej nieaktualnych znaczeń, a oni muszą go opanować, aby funkcjonować w tym świecie, który postrzegają jako coraz bardziej nieprzyjazny, a przede wszystkim zmierzający ku katastrofie. Świecie — dodajmy — urządzonym i doprowadzonym do obecnego stanu przez dzisiejszych dorosłych. Nauczyciele zaś nieraz z ogromnym trudem i dużą kreatywnością próbują przybliżyć

${ }^{1}$ O. Tokarczuk: Czuly narrator. Wydawnictwo Literackie, Kraków 2020 [e-book, format epub], s. 321 z 338. To zdanie stanowi punkt wyjścia rozważań Edwina Bendyka w jego diagnozie współczesnego świata (W Polsce, czyli wszędzie. Rzecz o upadku i przyszłości świata. Polityka, Warszawa 2020 [e-book, format epub]).

2 O. Tokarczuk: Czuly narrator..., s. 318 z 338 .

${ }^{3}$ Zob. P. Bourdieu, J.C. Passeron: Reprodukcja. Elementy teorii systemu nauczania. Przeł. E. Neyman. Wyd. 2. Wydawnictwo Naukowe PWN, Warszawa 2006. Na przykładzie polskich podręczników szkolnych interesująco pokazuje to zjawisko Lucyna Kopciewicz (Podręczniki szkolne jako narzędzie przemocy symbolicznej. W: Gender w podręcznikach. Projekt badawczy. Raport. T. 1: O projekcie. Metodologia badań. Wprowadzenie teoretyczne. Red. I. Chmura-Rutkowska et al. Fundacja Feminoteka, Warszawa 2016. Pobrano z: https://repozytorium.amu.edu. pl/bitstream/10593/23643/1/Gender-w-podr\%C4\%99cznikach.-Raport-Tom-1.pdf [15.07.2021], s. $81-92)$. 
uczniom teksty, których tematyka i styl zupełnie nie odpowiadają współczesnej rzeczywistości i wrażliwości młodych ludzi.

Pandemia stała się kryzysem - a zatem i szansą — który dobitnie unaocznił i wyostrzył kondycję współczesnej edukacji. Niebezpieczeństwo polega między innymi na tym, że zachowanie status quo nie tylko nie pomoże w rozwiązywaniu tych problemów, ale może wręcz je pogłębiać — choćby dlatego, że zaniechania edukacyjne i rozziew między edukacją a pozaszkolną rzeczywistością rodzić będą narastające frustracje i/lub gniew oraz podziały (głównie pokoleniowe). W moim przekonaniu doszliśmy do takiego momentu, w którym nie powinniśmy dłużej ignorować tego stanu rzeczy.

Swoje rozważania zacznę od próby diagnozy problemów współczesności, skonfrontuję to krótko $\mathrm{z}$ treściami nauczania określonymi w podstawie programowej oraz sytuacją uczniów i studentów, by wreszcie - żeby nie poprzestać na pesymizmie wyłaniającym się z diagnozy — naszkicować kilka propozycji rozwiązań, być może wartych rozważenia w edukacji polonistycznej, a przede wszystkim literackiej. Wierzę bowiem — być może naiwną wiarą humanisty że polonistyka nie jest skansenem, ale wciąż może pomagać zrozumieć rzeczywistość (jakakolwiek ona jest) oraz radzić sobie z nią.

\section{Problemy ze współczesnością: wspólnota, środowisko, poznanie}

Problemy z naszą współczesnością można — moim zdaniem — sprowadzić przynajmniej do trzech wielowymiarowych kryzysów: wspólnoty, środowiska naturalnego oraz - ujętego w nieco innym porządku — poznania.

Kryzys wspólnoty ujawnia się w problemach z tym, co umożliwia funkcjonowanie zbiorowości i tworzących je jednostek, czyli konfliktach w zakresie niezbędnych i współdzielonych przekonań dotyczących zasad, regulacji i wartości. Polega na tym, że za sprawą kwestionowania tego wspólnego mianownika dochodzimy do sytuacji, w której coraz trudniej współpracować i dążyć do celów możliwych do osiągnięcia jedynie w toku współpracy. Skutkuje to różnego rodzaju konfliktami i utrwala podziały, rodzi gniew i frustrację, a to z kolei różne formy dyskryminacji i wykluczenia. Myślę tu o szeroko rozumianych wojnach kulturowych związanych z polityką tożsamości ${ }^{4}$, o kryzysie

${ }^{4}$ Zob. M.P. Markowski: Wojny nowoczesnych plemion. Spór o rzeczywistość w epoce populizmu. Wydawnictwo Karakter, Kraków 2019 [e-book, format epub]; A. Sikora: Wolność, równość, 
kapitalizmu (w tym o starzeniu się społeczeństw, rosnącym rozwarstwieniu dochodów, automatyzacji pracy) $)^{5}$, kryzysie ekonomicznym i politycznym związanym z rozwojem populizmu i zmierzchem demokracji ${ }^{6}$.

W polskich realiach na wojny kulturowe nakłada się dziedzictwo przeszłości, często nieprzepracowane lub nieuobecnione wystarczająco w pamięci zbiorowej, jak kwestia statusu (niewolnictwa!) chłopów ${ }^{7}$ oraz powojenna latencja ${ }^{8}$, na który to stan wpłynęły dwa istotne doświadczenia zbiorowe: Holokaust i reforma rolna9.

Kanon lektur szkolnych w przeważającej mierze obrazuje przeszłość, która nie była udziałem większości naszych przodków, więc nie wynika z odziedziczonej pamięci zbiorowej naszych rodzin. Trudno, rzecz jasna, wykazać, jakie to ma znaczenie, ale uważam, że ten rozziew między konstruowanym w szkole i pewnych obszarach dyskursu publicznego obrazem przeszłości i wspólnoty narodowej a doświadczeniem większości dzisiejszych Polaków i ich przodków nie jest bez znaczenia.

Kryzys środowiska naturalnego wydaje się jeszcze bardziej dotkliwy ${ }^{10}$. Kwestie dotyczące ekologii i klimatu oraz sytuacji zwierząt budzą dziś silne emocje, z jednej strony bowiem odnoszą się do obszarów kluczowych dla funkcjonowania społeczeństw i gospodarek, z drugiej zaś bezpośrednio dotyczą każdego z nas, choćby dlatego, że środowisko wpływa na stan zdrowia człowieka. To staje się kolejną przyczyną procesów alienacyjnych, pogłębiających podziały między światem młodych ludzi a edukacją.

Kryzys poznawczy nasila wspomniane problemy. Objawia się w narastających trudnościach związanych z poznawaniem i rozumieniem naszej rzeczywistości, która staje się dla nas coraz bardziej złożona i tym samym niezrozumiała. Jednocześnie dlatego, że funkcjonujemy w bańkach poznawczych kształtowa-

przemoc. Czego nie chcemy sobie powiedzieć. Wydawnictwo Karakter, Kraków 2019 [e-book, format epub].

${ }^{5}$ Zob. więcej na ten temat: E. Bendyk: W Polsce, czyli wszędzie..., szczególnie rozdział: Koniec społeczeństwa.

${ }^{6}$ Zob. A. Applebaum: Zmierzch demokracji. Zwodniczy powab autorytaryzmu. Przeł. P. Tarczyński. Wydawnictwo Agora, Warszawa 2020 [e-book, format epub].

7 Zob. prace Jana Sowy, Daniela Beauvois, Michała Rauszera czy Adama Leszczyńskiego. Jak się wydaje, ta zmiana wrażliwości przekłada się także na odczytywanie literatury, czego przykładem może być odczytanie Chłopów dokonane przez Ryszarda Koziołka (Bierność polityczna chłopów. W: Idem: Wiele tytułów. Wydawnictwo Czarne, Wołowiec 2019 [e-book, format epub]).

${ }^{8}$ Zob. H.U. Gumbrecht: Po roku 1945. Latencja jako źródto współczesności. Tłum. A. Paszkowska. Wstęp A. Krzemiński. Wydawnictwo Krytyki Politycznej, Warszawa 2016.

${ }^{9}$ Zob. A. Leder: Prześniona rewolucja. Ćwiczenie z logiki historycznej. Wydawnictwo Krytyki Politycznej, Warszawa 2014.

${ }^{10}$ Zob. syntetyczne omówienie: E. Bendyk: W Polsce, czyli wszędzie..., rozdziały: Koniec natury. Antropocen i Nowy rezim klimatyczny. 
nych między innymi przez media ${ }^{11}$ i cyfrowe korporacje ${ }^{12}$, nie potrafimy sobie poradzić z dostępną wiedzą, dyskursami i innymi instrumentami poznawczymi, tym bardziej że uświadomiliśmy sobie w ostatnich latach, jak bardzo są one tak jak sama nauka — niedoskonałe, względne lub wręcz niewiarygodne. Dochodzi do tego nasilanie się procesu ,utowarowienia” wiedzy ${ }^{13}$. Skutkiem tych procesów jest w najlepszym wypadku poczucie zagubienia, w gorszym — ,cyfrowa demencja"14 oraz rozprzestrzenianie się postprawd, fake newsów, a także propagujących je ruchów społecznych i politycznych, które radykalizują życie społeczne ${ }^{15}$.

Z kryzysu poznawczego wynika kryzys sensu i sensowności tego, co i jak robimy ${ }^{16}$. Ostatnie dekady podważyły naszą pewność zarówno co do priorytetów oraz celów działań jednostek i zbiorowości, jak i co do sposobów ustalania tychże hierarchii działań i autorytetów. Kryzys sensowności może mieć dewastujące społecznie i egzystencjalnie skutki. Płynie z tego wniosek, że coraz bardziej kluczowym i dotkliwym pytaniem, które należy nieustannie zadawać, jest: „po co?”; do tej kwestii jeszcze wrócę w dalszej części artykułu.

W tak kryzysowej sytuacji wybuchła pandemia. Jak wpłynęła na nas i świat? Przede wszystkim pandemia stała się, zdaniem Slavoja Žižka, swoistym ,,asamblażem"

patogennego mechanizmu wirusowego, rolnictwa przemysłowego, szybkiego globalnego rozwoju gospodarczego, zwyczajów kulturowych, eksplozji komunikacji międzynarodowej itd. Epidemia to mieszanka, w której naturalne, gospodarcze i kulturowe procesy są ze sobą nieodłącznie związane $^{17}$.

${ }^{11}$ Zob. M. Taibbi: Nienawiść sp. z o.o. Jak wspótczesne media każa nam gardzić soba nawzajem. Przeł. T.S. Gałązka. Wydawnictwo Czarne, Wołowiec 2020 [e-book, format epub].

${ }_{12}$ Zob. S. Zuboff: Wiek kapitalizmu inwigilacji. Walka o przyszłość ludzkości na nowej granicy władzy. Tłum. A. Unterschuetz. Zysk i S-ka Wydawnictwo, Poznań 2020 [e-book, format epub].

${ }^{13}$ Zob. B. Stiegler: Wstrzasy. Glupota i wiedza w XXI wieku. Przekł. M. Krzykawski. Wydawnictwo Naukowe PWN, Warszawa 2017 [e-book, format epub]. Stiegler rozpatruje współczesne kłopoty z wiedzą oraz systemem edukacji w filozoficznym kontekście, a ich źródła wskazuje między innymi w „dialektyce oświecenia”.

${ }_{14}$ Zob. M. Spitzer: Cyfrowa demencja. W jaki sposób pozbawiamy rozumu siebie i swoje dzieci. Przeł. A. Lipiński. Wydawnictwo Dobra Literatura, Słupsk 2013.

15 Ostatnio przenikliwie zanalizowała to zjawisko Anne Applebaum (Zmierzch demokracji..., szczególnie rozdział: Strumienie kłamstw). Mechanizm ulegania prostym narracjom przedstawia też Yuval Noah Harari (rozdział Sens. W: Idem: 21 lekcji na XXI wiek. Przeł. M. Romanek. Wydawnictwo Literackie, Kraków 2018 [e-book, format epub]).

${ }^{16}$ Przygnębiającym tego świadectwem są diagnozy D. Graebera dotyczące pracy (Praca bez sensu. Teoria. Przeł. M. Denderski. Wydawnictwo Krytyki Politycznej, Warszawa 2019).

17 S. Žižek: Pandemia! COVID-19 trzęsie światem. Przekł. J. Maksymowicz-Hamann. Wydawnictwo Relacja, Warszawa 2020 [e-book, format epub], s. 83 z 98. Jean-Luc Nancy używa 
Być może pandemię należy — jak czyni to Olga Tokarczuk ${ }^{18}$ czy Iwan Krastew $^{19}$ - uznać za „czarnego łabędzia”, którego niespodziewane pojawienie się zmienia nieodwołalnie reguły ${ }^{20}$. Nietrudno zauważyć, że w pewnej mierze do obecnej sytuacji doprowadziły wspomniane kryzysy. Kryzys związany ze środowiskiem naturalnym nie tylko stał się niemal bezpośrednią przyczyną pandemii, lecz także potęguje niektóre problemy związane z jej rozwiązaniem oraz grozi kolejnymi podobnymi katastrofami. Kryzys poznawczy utrudnia zrozumienie sytuacji i tego, co z niej wynika, a wraz z kryzysem wspólnoty niekorzystnie wpływa na porozumienie w obrębie zbiorowości i skuteczność działania. Niezależnie jednak od realnego stopnia wpływu tych problemów na obecną sytuację wyraźnie zmienił się stan naszej świadomości zbiorowej: pandemiczna optyka sprawiła, że zarysowane kryzysy i problemy stały się dla nas bardziej zauważalne i dotkliwe lub spojrzeliśmy na nie z innej perspektywy.

Z pewnością zaś najważniejszą lekcją, jaka wynika z pandemii, jest taka, że świat ulega nieraz gwałtownym i nieprzewidywalnym zmianom, do których nie jesteśmy przygotowani, zatem kluczowe staje się pytanie, czy wobec „skrajnej niepewności [...] potrafimy kolektywnie pogodzić się z absolutnym brakiem kontroli nad naszą historią" ${ }^{21}$, skoro ,jedyną stałą jest zmiana" ${ }^{22}$. To oczywista konstatacja, dziś jednak to, co dawniej było zaledwie przedmiotem namysłu filozofów, za sprawą pandemii stało się naszą bezpośrednio doświadczaną codziennością. I choć trudno oczywiście ocenić w tej chwili, jakie będą długotrwałe konsekwencje pandemii - społeczne, ekonomiczne, kulturowe, ale też psychiczne ${ }^{23}$, egzystencjalne — to, jak się wydaje, nie można już ignorować tych kryzysów.

Naszkicowanie tej panoramy kryzysów pozwala nam uświadomić sobie, z jak obszernym i zróżnicowanym zakresem problemów przychodzi nam się zmagać, oraz wyraźniej zobaczyć rozziew między edukacją a współczesnym światem.

metafory „lustra powiększającego” (Arcyludzki wirus. Przekł. A. Dwulit. Wydawnictwo Ostrogi, Kraków 2021, s. 64).

${ }^{18}$ O. Tokarczuk: Czuly narrator..., s. 25-26 z 338.

19 I. Krastew: Nadeszło jutro. Jak pandemia zmienia Europę. Przeł. M. Sutowski. Wydawnictwo Krytyki Politycznej, Warszawa 2020, s. 5.

${ }^{20}$ N.N. Taleb: Czarny tabędź. Jak nieprzewidywalne zdarzenia rządza naszym życiem. Przeł. O. Siara. Zysk i S-ka Wydawnictwo, Poznań 2020 [e-book, format epub].

${ }^{21}$ J.L. Nancy: Arcyludzki wirus..., s. 98, 101. Francuski filozof zdaje się wierzyć, że skłoni nas to do ,prawdziwej rewolucji ducha”.

${ }^{22}$ Y.N. Harari: 21 lekcji na XXI wiek..., s. 280. Podobnie twierdzi N.N. Taleb, który pokazuje jednocześnie daremność naszych prób prognozowania przyszłych kryzysów (zob. N.N. Taleb: Antykruchość. Jak żyć w świecie, którego nie rozumiemy. Przeł. O. Siara. Zysk i S-ka Wydawnictwo, Poznań 2020 [e-book, format epub], s. 14 i nast. z 540).

${ }_{23}$ Zob. M. Kossowska et al.: Człowiek w obliczu pandemii. Psychologiczne i spoleczne uwarunkowania zachowań w warunkach kryzysu zdrowotnego. Smak Słowa, Sopot 2020. 


\section{Treści kształcenia i uczniowie}

Nie będzie specjalnie odkrywcze stwierdzenie, że podstawa programowa (dotycząca wszystkich etapów edukacyjnych) zawiera niewiele treści pozwalających zmierzyć się z zarysowanymi problemami współczesności ${ }^{24}$. Na liście lektur dla uczniów szkoły podstawowej bodaj jedynie Felix, Net $i$ Nika oraz Gang Niewidzialnych Ludzi odnosi się wyraźniej do doświadczeń współczesnych dzieci ${ }^{25}$; to zresztą jedyna pozycja w miarę aktualna, pozostałe są co najmniej sprzed pół wieku, większość zaś jest dużo starsza. Podobnie w przypadku szkoły ponadpodstawowej. Lista lektur dla uczniów szkoły średniej w większości składa się z kanonu literatury polskiej, niewiele tam pozycji nowszych i z kręgu współczesności. Na liście znalazła się (na szczęście!) Olga Tokarczuk, ale $\mathrm{z}$ tekstem dotyczącym realiów stanu wojennego...

Oczywiście wielu nauczycieli $-\mathrm{z}$ dużym trudem i zaangażowaniem kształci uczniów do mierzenia się ze współczesnością, a robi to na miarę polonistycznych i szkolnych możliwości. Podobnie w refleksji metodycznej pojawia się dużo interesujących propozycji. Niestety ramy edukacji wyznaczane są podstawą programową i systemem egzaminacyjnym, a te w obecnej formie nie pozostawiają wiele czasu i pola manewru, aby wprowadzać tak istotne dziś treści.

Warto zadać pytanie: jacy są dzisiejsi uczniowie (i studenci) ${ }^{26}$ ? Można opisać naszych podopiecznych przez pryzmat trzech aspektów: sposobów zdobywania przez młodych ludzi wiedzy (i konsekwencji tych działań poznawczych), a także lęków oraz oczekiwań, jakie wyrażają oni wobec edukacji.

Jeśli chodzi o zdobywanie wiedzy o świecie, to różnice między dzisiejszym pokoleniem a poprzednimi są dość oczywiste i związane z „usieciowieniem”. Dla większości młodych ludzi literatura czy inne znane dorosłym sposoby zdobywania wiedzy są czymś wysoce nieprzyjaznym i niezrozumiałym, a to może stać się źródłem pogłębienia podziałów pokoleniowych.

Młodzi mierzą się nie tylko z lękami rozwojowymi, ale będą musieli ponosić konsekwencje nierozwiązywania zarysowanych globalnych kryzysów; dzisiejszych nastolatków zapewne czeka gorsza przyszłość niż ich rodziców ${ }^{27}$.

${ }^{24}$ Zastrzeżenia do obowiązującej podstawy programowej omawia syntetycznie Dariusz Szczukowski (Praktykowanie lektury. Wydawnictwo Uniwersytetu Gdańskiego, Gdańsk 2019, s. $66-71)$.

${ }^{25} \mathrm{~W}$ propozycjach zmian na liście lektur przedstawionych przez ministerstwo ta lektura została zresztą usunięta...

${ }^{26}$ Niezwykle interesujący ogląd sytuacji dają badania Przemysława Sadury (Państwo, szkoła, klasy. Warszawa 2018 [e-book, format epub]).

${ }^{27}$ Zob. np. P. Długosz: Pokolenie przegranych? Kondycja psychospołeczna młodzieży w Europie Środkowo-Wschodniej. „Zeszyty Pracy Socjalnej” 2016, T. 21, z. 2, s. 77—90. https:// doi.org/10.4467/24496138PS.16.006.6276 (szczególnie s. 80 i nast.). 
Pandemia jeszcze bardziej zaburzyła poczucie stabilności i przewidywalności młodego pokolenia, prawdopodobnie odczuło ono jej skutki dużo dotkliwiej niż dorośli $i^{28}$. Niedługo zatem będziemy mieli do czynienia w szkołach i na uczelniach z podopiecznymi doświadczającymi znaczenie silniejszych (i - dodajmy — w pełni uzasadnionych!) lęków niż te, które były udziałem niedawnych absolwentów.

Dobrą ilustracją lęków młodych ludzi jest wypowiedź Grety Thunberg wygłoszona na Światowym Forum Ekonomicznym w 2019 roku: „Nasz dom, Ziemia, płonie! Chcę, żebyście panikowali i żyli tak jak ja w strachu i panice"29. Warto pamiętać, że z perspektywy młodych ludzi to my i nasze działania w tym system edukacyjny — jesteśmy odpowiedzialni za kształt i stan dzisiejszego świata.

Oczekiwania młodych ludzi wobec edukacji są bardzo zróżnicowane, zależą także od tego, z jakich klas społecznych uczniowie się wywodzą: może im zależeć na zdobywaniu wiedzy dla niej samej i samorozwoju, na awansie społecznym czy też zdobyciu praktycznych umiejętności życiowych i zawodowych. Różnice w motywacjach do nauki wpływają na kształt modeli uczenia i ich rozpiętość: od swobodnego podejścia do reguł i dyscypliny szkolnej przez oczekiwanie takich właśnie ram aż po ich ignorowanie ${ }^{30}$. Rodzi to, co oczywiste, zróżnicowane postawy wobec systemu szkolnego.

Należy wspomnieć ponadto o skutkach zdalnego nauczania w czasie pandemii. Z perspektywy młodych ludzi (i nauczycieli) taka edukacja poważnie zdewaluowała uczenie oparte na biernym przekazywaniu wiedzy i jej egzekwowaniu ${ }^{31}$. Niezbędne okazało się kształtowanie kompetencji, których młodzi

${ }^{28}$ Zob. Stanowisko 10. zespolu ds. COVID-19 przy Prezesie PAN: Konsekwencje pandemii COVID-19 dla zdrowia psychicznego i edukacji dzieci i mtodzieży. Polska Akademia Nauk, 25.01.2021. https://informacje.pan.pl/index.php/informacje/materialy-dla-prasy/3233-stanowisko -10-zespolu-ds-covid-19-przy-prezesie-pan-konsekwencje-pandemii-covid-19-dla-zdrowia-psychicznego-i-edukacji-dzieci-i-mlodziezy [dostęp: 19.04.2021].Zob. też:A. Kalita: 10-letnie dziecko mówi: , Mamy kredyt. Boję się, co będzie, jak rodzice straca pracę”. [Rozmowa z Justyną Britmann]. Weekend.gazeta.pl, 19.01.2021. https:/weekend.gazeta.pl/weekend/1,177333,26698880,10-letnie-dziecko-mowi-mamy-kredyt-boje-sie-co-bedzie-jak.html [dostęp: 30.01.2021].

${ }^{29}$ Cyt. za: E. Bendyk: W Polsce, czyli wszędzie..., s. 35 z 450.

${ }_{30}$ Zob. P. Sadura: Państwo, szkoła, klasy..., s. 83-87 z 270.

${ }^{31}$ Zob. A. Buchner, M. Wierzbicka: Edukacja zdalna w czasie pandemii. Raport. Edycja II. Listopad 2020. Pobrano z: https://centrumcyfrowe.pl/wp-content/uploads/sites/16/2020/11/Raport_Edukacja-zdalna-w-czasie-pandemii.-Edycja-II.pdf [19.04.2021], szczególnie s. 95-96; zob. też świadectwa nauczycieli: J. Biszewska: Polonistka: Zdalnie to możemy sobie porozmawiać przez telefon, ale nie uczyć. [Rozmowa z Małgorzatą Próchniak]. Edziecko, 4.03.2021. https:// www.edziecko.pl/Junior/7,160035,26826742,polonistka-zdalnie-to-mozemy-sobie-porozmawiac -przez-telefon.html\#s=BoxMMt3 [dostęp: 4.03.2021]; A. Borodaj: „Zachodzę pod dom ucznia, proszę, żeby stanąt $w$ oknie, pomacham, pożartuję przez ptot. Tyle mogę”. Weekend.gazeta.pl, 4.02.2021. https://weekend.gazeta.pl/weekend/7,177334,26756212,zachodze-pod-dom-uczniaprosze-zeby-stanal-w-oknie-pomacham.html [dostęp: 19.04.2021]. 
ludzie - również za sprawą obecnego systemu kształcenia - nie posiadają w wystarczającym stopniu, a chodzi o samokształcenie (zapisane w podstawie programowej, ale w zakresie nieadekwatnym do realiów pandemii), krytyczne myślenie i umiejętność weryfikacji źródeł, samodyscyplinę oraz bardziej zaawansowane korzystanie z narzędzi informatycznych. Jak się wydaje, uczniowie boleśnie doświadczyli tych deficytów, a jednocześnie odczuli brak zasadności nauczania opartego na reprodukowaniu wiedzy.

Należy uznać - w podsumowaniu — że mamy do czynienia $\mathrm{z}$ nagromadzeniem lęków i oczekiwań młodych ludzi, na które obecna edukacja nie odpowiada lub odpowiada w niewielkim stopniu. Narastający rozziew między wyzwaniami współczesności oraz kondycją uczniów i studentów a edukacją (też polonistyczną) powiększać będzie zapewne kryzys wspólnoty, a to będzie rodzić nieuchronne i coraz silniejsze konflikty.

\section{Propozycje rozwiązań: jak mierzyć się z problemami współczesności w edukacji literackiej}

Wniosek z przedstawionej diagnozy płynie następujący: obecny stan rzeczy wymaga, aby istotnie przemyśleć, a w konsekwencji przebudować edukację, w tym edukację polonistyczną.

Edukacja powinna, w mojej opinii, skupić się na rozwijaniu wrażliwości (na innych ludzi i ich przekonania oraz potrzeby, a także na problemy środowiska naturalnego i zwierząt), tolerancji i odpowiedzialności (za ludzi i naturę) oraz kompetencji społecznych sprzyjających realizacji wspólnych celów. Istotne jest uczenie rozumienia i funkcjonowania w świecie wielości światopoglądów, wartości, postaw, tożsamości, również poprzez umiejętność prowadzenia dialogu. W zakresie umiejętności poznawczych należy rozwijać zdolność krytycznego myślenia ( $w$ tym weryfikowania źródeł), poznawania i rozumienia różnych perspektyw, światopoglądów, emocji, postaw — pozwoli to mierzyć się nieco skuteczniej z kryzysem poznawczym. Edukacja winna też oswajać z nieprzewidywalnością życia i świata — to być może najistotniejszy postulat $!^{32}$ — oraz przygotowywać na różne, $\mathrm{w}$ tym trudne, doświadczenia egzystencjalne poprzez kształtowanie postawy odporności (resilience) ${ }^{33}$, czemu sprzyja kształcenie

32 Tak twierdzi Harari (21 lekcji na XXI wiek..., s. 282 z 380).

${ }^{33}$ Zob. krótki przegląd ujęć w: A. Borucka, A. Pisarska: Koncepcja resilience - czyli jak pomóc dzieciom i młodzieży z grup podwyższonego ryzyka. Ośrodek Rozwoju Edukacji. Pobrano z: https://bezpiecznaszkola.men.gov.pl/projekty/Borucka_Pisarska.pdf [27.09.2021]. 
szeroko rozumianych kompetencji społecznych i komunikacyjnych ${ }^{34}$. I wreszcie istotne jest, aby budzić nadzieję — edukacja nie powinna być tylko reaktywna i retrospektywna, lecz także proaktywna i prospektywna, kształtująca poczucie sprawczości.

\section{Dlaczego język polski?}

Warto postawić pytanie, co z tej diagnozy stanu dzisiejszej edukacji miałoby wynikać dla edukacji polonistycznej. Można powiedzieć, że niewiele — przecież język polski w szkole ma swoje wyzwania i zadania, być może uniwersalne, i nie do szkolnych polonistów należy reagowanie na omówione kryzysy. Dlaczego dokładać polonistyce szkolnej kolejne misje, treści, formułować kolejne wobec niej oczekiwania?

Po pierwsze, mamy do czynienia z tak dużym spiętrzeniem kryzysów i lęków z nimi związanych, że edukacja — nie tylko polonistyczna — nie powinna tego stanu rzeczy ignorować.

Po drugie, nasz obraz świata jest kształtowany w dużej części przez język i teksty — są one zarówno źródłem problemów (na przykład w wypadku mowy nienawiści czy wykluczenia), jak i diagnozy problemów oraz propozycji rozwiązań. Polonistyka ma właściwe zasoby, aby poprzez świat tekstów wprowadzać do utekstowionego świata, co oczywiście od dawna robi ${ }^{35}$.

Po trzecie, z tego właśnie względu język polski jest przedmiotem podstawowym, uczącym myślenia oraz artykułowania uczuć i poglądów, dialogu i dyskusji — to wyliczenie można by jeszcze rozwijać i doprecyzowywać.

Po czwarte, język polski jest przedmiotem węzłowym, integrującym, zastępującym siłą rzeczy przedmioty, których w szkole nie ma (jak psychologia czy socjologia) albo które są obecne marginalnie (jak etyka czy filozofia). Ta integracja sprzyja patrzeniu z wielu perspektyw na świat, toteż jako przedmiot węzłowy i podstawowy język polski nie powinien uciekać od wyzwań współczesności, ale je podejmować, nawet kosztem rozwijania tradycyjnych (często już anachronicznych) specjalistycznych obszarów i problemów. To zwolnienie miejsca dla nowych treści, czyli pewna marginalizacja treści polonistycz-

${ }^{34}$ Zob. M. Smulczyk: „Resilience” a edukacja. Rola fenomenu skutecznej adaptacji w osiagnięciach szkolnych. „Forum Oświatowe” 2016, [nr] 28 (2), s. 214 i nast.

${ }^{35}$ Zwykle cele edukacji polonistycznej zawężane są do znajomości i rozumienia kultury (zob. sformułowania celów z popularnych podręczników: E. Nowak: Cele edukacji polonistycznej. W: Polonista w szkole. Podstawy ksztatcenia nauczyciela polonisty. Red. A. Janus-Sitarz. Universitas, Kraków 2004, s. 19-21), przy czym kultura utożsamiana jest tu z jej wysokim rejestrem (ewentualnie z elementami kultury popularnej). Jeśli jednak rozszerzymy pojęcie kultury o to, czym dziś ona jest dla młodych ludzi, tych celów nie ma potrzeby zmieniać. 
nych na rzecz ważniejszych problemów ludzkości, jest w moim przekonaniu konieczne.

Po piąte, $\mathrm{z}$ wymienionych już względów nie ma chyba innego przedmiotu szkolnego, który umożliwiałby zasadne zajmowanie się różnorodnymi tekstami, a za ich sprawą wielorakimi przekonaniami i uczuciami, tematami i problemami. To na lekcjach polskiego można zmierzyć się z tymi kwestiami, które wymykają się ścisłej przedmiotowej klasyfikacji i mają charakter interdyscyplinarny.

Po szóste, literatura niejednokrotnie podejmuje te nieproste i wieloaspektowe problemy oraz wydaje się mieć nieoceniony potencjał w pielęgnowaniu złożoności świata i jego wielowymiarowości, jest — jak pisze Tokarczuk — „krainą Metaksy”36 — światem „pomiędzy”, pielęgnującym nieoczywistości, wieloznaczności. Trzeba jednak dodać, że rola i ranga literatury oraz siła jej oddziaływania, szczególnie na młodych, są dziś istotnie mniejsze niż kiedyś, więc wykorzystanie literatury do realizacji zarysowanych celów i z tego względu powinno być skromniejsze ${ }^{37}$.

Po siódme, podobnym do literatury potencjałem wykazuje się humanistyka, która wypracowała różne narzędzia, diagnozy i projekty pozwalające mierzyć się z wyzwaniami współczesności. Kształcenia wrażliwości i tolerancji domaga się w zwrotach kładących nacisk na dyskryminację, wykluczenie, różne formy przemocy (na przykład zwrot kulturowy, etyczno-polityczny, feminizm, badania genderowe, posthumanizm) ${ }^{38}$. Te same nurty - ze zwrotem etycznym i postantropocentryzmem na czele - postulują kształtowanie odpowiedzialności. Hermeneutyki (szczególnie podejrzeń) rozwijają umiejętność rozumienia, ale też demaskowania. Uczenie pluralizmu jest również humanistyczną oczywistością, warto podkreślić jej rolę dla rozwoju demokracji ${ }^{39}$. Traktowanie humanistyki jako terapii oswajającej z niepewnością świata i egzystencji ma długą tradycję ${ }^{40}$, podobnie jak korzystanie z humanistyki do budowania

${ }^{36}$ O. Tokarczuk: Czuly narrator..., rozdział: Kraina Metaksy.

${ }^{37}$ Przede wszystkim pamiętać należy, że literatury nie sposób traktować jako prostego narzędzia wychowawczego, o czym przenikliwie pisał Janusz Sławiński (Literatura w szkole: dziś i jutro. W: Idem: Teksty i teksty. Universitas, Kraków 2000, s. 96-97).

${ }^{38} \mathrm{O}$ humanistyce opartej na kategorii wrażliwości wprost pisał Michał Paweł Markowski (Polityka wrażliwości. Wprowadzenie do humanistyki. Universitas, Kraków 2013).

${ }^{39}$ Zob. M.C. Nussbaum: Nie dla zysku. Dlaczego demokracja potrzebuje humanistów. Przeł. Ł. Pawłowski. Przedmowa J. Kuisz. Fundacja Kultura Liberalna, Warszawa 2016.

${ }^{40}$ Zob. np. M. Janion: Humanistyka. Poznanie i terapia. Państwowy Instytut Wydawniczy, Warszawa 1974; też: O. Marquard: Opóźniona moralistyka. Uwagi o nieodzowności humanistyki. W: Idem: Szczęście w nieszczęściu. Rozważania filozoficzne. Przeł. K. Krzemieniowa. Oficyna Naukowa, Warszawa 2001, s. 108-115. Projekt kształtowania człowieka poprzez samorozwój do „uodparniania” na nieprzewidywalność zaproponował Peter Sloterdijk (Musisz życie swe odmienić. O antropotechnice. Przekł. J. Janiszewski. Słowo wstępne A. Żychliński. Wydawnictwo Naukowe PWN, Warszawa 2014 [e-book, format epub], szczególnie s. 40 i nast. z 625). 
nadziei i poczucia sprawczości ${ }^{41}$. Jesteśmy zatem w sytuacji, w której nie jest konieczne wypracowywanie nowych konceptów ${ }^{42}$, ale aplikacja już istniejących oraz odpowiednie ich usytuowanie w hierarchii naukowych i dydaktycznych działań.

Wreszcie, po ósme, polonistyczni metodycy poddawali już wymienione kwestie refleksji — formułowali (także niedawno) bardzo ważne postulaty, w których domagali się uwzględniania w edukacji polonistycznej problemów współczesności ${ }^{43}$, szczególnie wielokulturowości ${ }^{44}$ czy sytuacji zwierząt oraz klimatu ${ }^{45}$. To kolejny argument świadczący o tym, że dydaktyka polonistyczna jest gotowa mierzyć się z tymi wyzwaniami.

Konieczna jest jednak zmiana dominanty. Słuszne postulaty najczęściej artykułowano dotąd zgodnie z logiką — być może jedyną możliwą w obecnej sytuacji — suplementacji, to znaczy dodawania kolejnych treści i zobowiązań do już i tak przeładowanej polonistycznej dydaktyki. Sądzę, że ten trend należałoby odwrócić: punktem wyjścia powinno być określenie zobowiązań szkoły i szkolnej polonistyki wobec współczesnego świata, później dostosowanie do tego narzędzi i możliwości dydaktycznych, a następnie ewentualne uzupełnienie dydaktyki polonistycznej o to, co wynika z naszej przedmiotowej, specjalistycznej perspektywy. Oznaczałoby to nie tylko wsłuchanie się w problemy współczesności, lecz także być może oddanie życzliwym niepolonistom (przedstawicielom nauk społecznych i przyrodniczych) prymatu w ustalaniu treści

${ }^{41}$ Np. E. Domańska: Historia ratownicza. „Teksty Drugie” 2014, nr 5, s. 12-26; R. Solnit: Nadzieja w mroku. Nieznane opowieści, niebywałe możliwości. Przeł. A. Dierzgowska, S. Królak. Wydawnictwo Karakter, Kraków 2019.

42 Krótkiego przeglądu dyskusji nad kształtem humanistyki w kontekście dydaktyki polonistycznej dokonał Dariusz Szczukowski (Praktykowanie lektury..., s. 11-38).

$43 \mathrm{~Np}$. K. Koc: Software w szkolnym ksztatceniu polonistycznym, czyli o znaczeniu aktualizacji teorii dydaktycznych. „Polonistyka. Innowacje” 2018, nr 7, s. 71-83. https://doi.org/10.14746/ pi.2018.1.7.6 (szczególnie s. 74); Idem: Wspótczesność „źle obecna” w szkole podstawowej, czyli o kryzysie edukacji humanistycznej. „Annales Universitatis Paedagogicae Cracoviensis. Studia ad Didacticam Litterarum Polonarum et Linguage Polonae Partinentia” 2019, s. 126 i nast. https:/doi. org/10.24917/20820909.10.12.

$44 \mathrm{~Np}$. K. Koc: Lekcje myślenia (obywatelskiego). Edukacja polonistyczna wobec wspótczesnego świata. Wydawnictwo Naukowe Uniwersytetu im. Adama Mickiewicza, Poznań 2018; B. Myrdzik: Wielokulturowa Europa jako wyzwanie edukacyjne. W: Eadem: Zrozumieć siebie i świat. Studia i szkice o edukacji polonistycznej. Wydawnictwo Uniwersytetu Marii Curie-Skłodowskiej, Lublin 2006, s. 393-417.

45 Np. M. Ochwat: Klimat - konflikty - migracje. Scenariusze przyszłości. „Postscriptum Polonistyczne" 2019, [nr] 2 (24), s. 55. https://doi.org/10.31261/PS_P.2019.24.04; Eadem: (Wspót)myślenie $w$ humanistyce. Literackie ekokształcenie $w$ epoce antropocenu. „Polonistyka. Innowacje" 2020, nr 12, s. 31-51. https://doi.org/10.14746/pi.2020.12.3; A. Jarzyna: $O$ czym myślę, kiedy myślę o zwierzętach w edukacji polonistycznej? Siedem odpowiedzi. „Polonistyka. Innowacje" 2020, nr 11, s. 63-76. https://doi.org/10.14746/pi.2020.11.6. 
kształcenia, filologom zaś pozostawienie zadania wypracowania metod i środków realizacji tych treści.

Niestety wciąż na wszelkich szczeblach edukacji dominuje swoisty „chów wsobny" - podstawy programowe oraz uniwersyteckie sylabusy piszą specjaliści z danej dziedziny, co skutkuje dążeniem do reprodukowania dyskursu swojej dyscypliny. Mam silne przekonanie, że w zakresie kształcenia niespecjalistycznego, ,z wnętrza” własnej dyscypliny, szczególnie w obecnej sytuacji, nie można właściwie ocenić wagi, potencjału, zasadności tego, co uczymy.

\section{Czego uczyć? Tematyki i poetyki}

Należy oczywiście zastanawiać się nad tym, czego uczyć oraz jak to robić. Ale coraz istotniejsze staje się pytanie „po co?”46, czyli także: do jakiego świata, do jakiej dorosłości przygotowujemy młodych ludzi. Bez wyraźnego i dobitnego udzielania uczniom odpowiedzi na to pytanie nie da się dziś, jak sądzę, skutecznie uprawiać dydaktyki na żadnym etapie edukacyjnym; grozić nam będzie narastające poczucie bezsensu i braku motywacji, u uczniów skutkujące coraz większą frustracją i alienacją wobec szkoły i dorosłych, u nauczycieli zaś wypaleniem zawodowym, które wydatnie jest związane z poczuciem braku sensu ${ }^{47}$.

Odpowiedź na pytanie ,po co się uczyć?” nie powinna mieć charakteru pragmatycznego (na przykład „,po to, aby zdać egzamin, a ostatecznie zdobyć pracę, która pozwoli na utrzymywanie się"). Warto zwracać uwagę - co wyraźniej jest widoczne w kontekście pandemii — na te cele, które służą samorozwojowi, kształtowaniu postaw i umiejętności, ponieważ to rozwija także kompetencje miękkie cenione na rynku pracy.

Czego zatem uczyć? Tu pozwolę sobie jedynie krótko i bardzo orientacyjnie sformułować pewne propozycje, wymagające, rzecz jasna, szerszego podkreślę: również niefilologicznego - namysłu oraz integracji z innymi przedmiotami. Nie będą to - bo nie muszą być — rozwiązania oryginalne, chodzi tu bowiem jedynie o wyodrębnienie i wyeksponowanie tego, co w dzisiejszych realiach stanowić powinno w moim przekonaniu dominantę edukacji literackiej.

${ }^{46}$ Wagę tego pytania podkreśla również Anna Janus-Sitarz (Humanistyka w poszukiwaniu zaginionego czytelnika. W: Edukacja polonistyczna jako zobowiazanie. Powszechność i elitarność polonistyki. T. 1. Red. nauk. E. Jaskółowa et al. Wydawnictwo Uniwersytetu Śląskiego, Katowice 2016, s. 56-58). Temat poruszono również w dyskusji panelowej poświęconej potrzebom współczesnej edukacji polonistycznej ( $W$ stronę nowej podstawy programowej języka polskiego. [Dyskusja panelowa online]. Organizator: Centrum Badań Edukacyjnych i Kształcenia Ustawicznego na Wydziale Polonistyki Uniwersytetu Jagiellońskiego, MS Teams, 19.04.2021).

47 Zob. D. Graeber: Praca bez sensu..., s. 146 i nast. 
Kształtowaniu wspomnianych umiejętności i postaw — wrażliwości, zrozumienia, tolerancji, odpowiedzialności, gotowości do współpracy, umiejętności rozumienia złożoności i nieprzewidywalności świata - sprzyjać powinna dbałość o wielość i różnorodność perspektyw, znaczeń, doświadczeń, emocji, a co za tym idzie, tematów, utworów, odczytań, pokazująca pozytywne aspekty różnic i potrzebę ich akceptacji.

Wielość i różnorodność sprzyjają krytycznemu myśleniu, a przede wszystkim unikaniu jednego z najważniejszych błędów poznawczych, czyli przekonania, że ,istnieje tylko to, co widzisz”, wyciągania wniosków i podejmowania decyzji tylko na podstawie dostępnych pod ręką danych ${ }^{48}$. Inaczej mówiąc, należy pokazywać i uświadamiać uczniom różnorodność świata i jego problemów oraz demonstrować możliwe ich rozwiązania. W wypadku omówionych kryzysów kluczowe są dwa obszary tematyczne, które za pomocą różnych tekstów należałoby w szkole wprowadzać możliwie jak najszerzej: tematyka nieantropocentryczna oraz wielokulturowość ( $w$ tym wielość perspektyw i światopoglądów).

$\mathrm{Z}$ pewnością powinniśmy $\mathrm{w}$ edukacji polonistycznej wyjść poza optykę i tematykę antropocentryczną. Należy rozwijać większą wrażliwość na świat wokół nas, na zwierzęta, rośliny, klimat i przedmioty. Nie brakuje przykładów wartościowych literacko utworów, także z zakresu literatury dla dzieci, podejmujących te kwestie ${ }^{49}$. Są wśród tych tekstów utwory wybitne literacko, łączące wrażliwość na przyrodę z troską o poetycki styl, jak Patyki, badyle Urszuli Zajączkowskiej.

Wielokulturowość i wielość perspektyw patrzenia na świat również można zilustrować dużą liczbą tekstów, przede wszystkim niefikcjonalnych, które warto wykorzystać w dydaktyce szkolnej ${ }^{50}$. Jak sądzę, trzeba też odchodzić od etnocentrycznej perspektywy - problemów współczesnego świata nie rozwiążemy w ramach wspólnot narodowych ${ }^{51}$, obecnie zatem istotniejsze jest budowanie tożsamości ponadregionalnej. Oznacza to także szersze niż dotąd dopuszczenie w edukacji polonistycznej tekstów w języku polskim, ale napisanych przez autorów z innych krajów i kultur.

${ }^{48}$ Zob. D. Kahneman: Pułapki myślenia. O myśleniu szybkim i wolnym. Tłum. P. Szymczak. Media Rodzina, Poznań 2012, s. 270.

49 Interesujące przykłady omówienia znajdziemy na przykład w tekstach Magdaleny Ochwat (Klimat - konflikty - migracje...; (Wspót)myślenie w humanistyce...), Eweliny Rąbkowskiej (Zwierzęta i ich dzieci - poznanie, empatia, etyka. Perspektywa ekokrytyczna w literaturze dla dzieci i młodzieży. W: P. Czapliński, J.B. Bednarek, D. Gostyński: Literatura i jej natury. Przewodnik ekokrytyczny dla nauczycieli i uczniów szkót średnich. Wydawnictwo Rys, Poznań 2017 [e-book, format epub], s. 67-93 z 428) czy Joanny Guszty (Przewodnik po ksiażkach ekologicznych dla dzieci. „Znak” 2021, nr 4 (791), s. 32-33).

${ }^{50}$ Obszerne omówienie licznych przykładów i ich możliwych szkolnych aplikacji zob.

K. Koc: Lekcje myślenia (obywatelskiego)..., s. 191-252.

${ }^{51}$ Y.N. Harari: 21 lekcji na XXI wiek..., s. 152-153 z 380. 
Jeszcze większym wyzwaniem edukacji, w tym edukacji literackiej, jest kształtowanie odporności (resilience) pozwalającej skutecznie mierzyć się z doświadczeniami trudnymi i zmiennością świata. Wymaga to znacznie szerszego zakresu działań (dotyczących całej szkoły i innych przedmiotów nauczania), a z pewnością uważniejszych studiów i badań ${ }^{52}$. Liczba zmiennych i czynników, które w tym wypadku wchodzą w grę, sprawia jednak, że ustalenie w dydaktyce polonistycznej skuteczności określonych działań kształtujących odporność wydaje się niemożliwe, co skazuje edukatorów/nauczycieli na pewną dozę intuicyjnego próbowania.

W zakresie edukacji literackiej możliwe są, w moim przekonaniu, trzy rodzaje działań: po pierwsze, dobór utworów i ich interpretacja przedstawiająca zachowania i postawy służące odporności, po drugie, wykorzystanie filozofii (szczególnie stoickiej), po trzecie, kształtowanie poczucia sprawczości za pomocą interpretacji tekstów oraz ich tworzenia.

Zalecenia Amerykańskiego Towarzystwa Psychologicznego służące kształtowaniu odporności (resilience) są następujące:

1) utrzymywanie dobrych relacji z dorosłymi członkami rodziny, którzy są otwarci i z którymi można tworzyć więź, z przyjaciółmi i nauczycielami;

2) unikanie patrzenia na sytuacje kryzysowe i stresowe jako na niemożliwe do rozwiązania;

3) akceptowanie niekorzystnych okoliczności jako okazji do zmiany oraz jako sytuacji, które są przejściowe;

4) stawianie sobie realnych celów i dążenie do nich;

5) traktowanie przeciwności losu jako sytuacji zwrotnych i decydujących w życiu, których rozstrzygnięcie zależy od nas;

6) traktowanie własnych doświadczeń zmagania się z losem jako nowych możliwości;

7) rozwój zaufania do siebie i swoich możliwości;

8) posiadanie szerszej perspektywy czasowej i patrzenie na swoje sytuacje kryzysowe w szerszym kontekście sytuacyjno-czasowym;

9) posiadanie nadziei, szukanie dobrych stron w wydarzeniach oraz posiadanie marzeń;

10) dbanie o swoje zdrowie psychofizyczne, regularne ćwiczenia, zwracanie uwagi na to, czego się potrzebuje i co czuje, pozytywne korzystanie z czasu wolnego oraz realizowanie swoich pasji ${ }^{53}$.

${ }^{52}$ Przykładowe programy wdrażane w szkołach omawia Marek Smulczyk (,Resilience” a edukacja...).

${ }_{53}$ M. Michel: Wzmacnianie czynników chroniacych $w$ tworzeniu bezpiecznej przestrzeni szkoły w programach liderów rówieśniczych w kontekśsie koncepcji resilience. „Resocjalizacja Polska / Polish Journal of Social Rehabilitation” 2014, [nr] 6, s. 108. 
Warto zadbać w edukacji literackiej o dobór odpowiednich tekstów (niekoniecznie literackich) i taką ich interpretację, która zwracałaby uwagę na wymienione wskazania.

Wykorzystanie filozofii jako formy działania terapeutycznego zgodne jest z jej pierwotną funkcją jako ćwiczenia duchowego ${ }^{54}$. Współcześnie renesans przeżywa stoicyzm, traktowany właśnie jako kształtowanie odporności (lub antykruchości) ${ }^{55}$, który rozwinął pomocną, jak się wydaje, praktykę uodparniania za pomocą, po pierwsze, wyobrażania sobie i oswajania potencjalnych negatywnych doznań, a po drugie, dostarczania sobie niewielkich stresorów pozwalających ,szczepić się” przeciw trudnym doświadczeniom.

Warto zatem uwzględniać teksty, które mówią o doświadczeniach i emocjach trudnych i bolesnych, związanych również z nieprzewidywalnością życia, co wydaje się szczególnie ważnym postulatem w kontekście pandemii. Nie ma chyba lepszego sposobu mówienia o tych doświadczeniach niż ten, który proponuje literatura - i dotyczy to zarówno dzieci, jak i dorosłych. To, że można to robić mądrze i z wyczuciem, pokazuje znany przykład Oskara i pani Róży Érica-Emmanuela Schmitta ${ }^{56}$.

Oswajanie z różnymi doświadczeniami pomagać może w rozwijaniu nadziei, sprawczości i wrażliwości na różnorodność świata. Wspiera też budowanie tożsamości i sensu własnego życia - narracje temu służące powinny bowiem spełniać dwa warunki: dawać jakąś rolę do odegrania, którą w życiu mógłby odgrywać czytelnik, oraz obejmować zakres większy niż horyzont odbiorcy, aby uczyć go przekraczania siebie ${ }^{57}$.

Wreszcie odporność jest kształtowana przez wzmacnianie poczucia sprawczości. Mogą temu sprzyjać dwie podstawowe kompetencje kształcone na lekcjach języka polskiego: interpretacja (a raczej lektura) oraz pisanie. Nie ma potrzeby przekonywania, że lektura inwencyjna, łącząca indywidualną perspektywę i doświadczenia z wiedzą, owocująca pokonaniem trudności (na przykład percepcyjnych, semantycznych), sprzyja budowaniu podmiotowości, a tym

${ }^{54}$ Zob. P. Hadot: Filozofia jako ćwiczenie duchowe. Przeł. P. Domański. Wydawnictwo Instytutu Filozofii i Socjologii PAN, Warszawa 1992.

${ }^{55}$ Zob. W.B. Irvine: Wyzwanie stoika. Jak dzięki filozofii odnaleźć w sobie siłe, spokój i odporność psychiczna. Przekł. O. Siara. Insignis, Kraków 2020; N.N. Taleb: Antykruchość...; P. Stankiewicz: Sztuka życia wedlug stoików. Grupa Wydawnicza Foksal - Wydawnictwo WAB, Warszawa 2014. Fragmenty tych książek z powodzeniem można wykorzystać w polonistycznej edukacji.

${ }^{56}$ Rzecz jasna, wskazana jest tu ostrożność, ponieważ „lektura rozpaczy [...] sprzyja jednak »łatwemu nihilizmowi«, rozpaczy ukradzionej” (K. Koziołek: Czas lektury. Wydawnictwo Uniwersytetu Śląskiego, Katowice 2017, s. 92).

${ }_{57}$ Zwraca na to uwagę w kontekście edukacji niefilolog Yuval Noah Harari (21 lekcji na XXI wiek..., s. 298 z 380). 
samym kształceniu poczucia sprawczości. Podobnie działa pisanie, szczególnie literackie „światotwórstwo”, czyli kreowanie własnych fikcyjnych światów, oraz aranżowanie takich sytuacji komunikacyjnych, w których uczniowskie teksty będą miały rzeczywisty performatywny efekt (nawet takich jak formułowanie podań i wniosków) ${ }^{58}$.

Edukacji uwrażliwiającej i oswajającej sprzyjać będzie ponadto wykorzystywanie aktualnych tekstów i tematów i/lub prezentyzm w ich ujęciu. Jestem przekonany, że na szkolnej liście lektur dominować powinny utwory możliwie współczesne uczniom. Można tu odwołać się do kategorii Stimmung, którą rozwija Hans Ulrich Gumbrecht, oznaczającej klimat, atmosferę, swoistą dyskretną namacalność, w której zawiera się zarówno uczuciowość (wrażliwość), jak i obiektywne uwarunkowania. Stimmung oddziałuje na nas tak, jak ,pogoda, dźwięki i muzyka mają na nas materialny, choć niewidzialny wpływ"59. Może dochodzić do głosu za pomocą tematyki utworów, stylu, sposobu obrazowania - raczej konstelacji różnych elementów niż tylko jednego czynnika, który trudno byłoby wskazać, choćby ze względu na afektywny charakter oddziaływania Stimmung (to zresztą dobór stosownych lektur czyni dość arbitralnym... $)^{60}$. Aby literatura przemawiała do młodych ludzi, powinna, jak sądzę, nieść z sobą współczesną im „nastrojowość”. Tylko w ten sposób ma szansę być żywo odbierana w szkole.

Stimmung dochodzi do głosu za sprawą różnych tekstów i źródeł — nie tylko literackich ${ }^{61}$. Warto zatem szerzej włączyć do szkolnych lektur utwory niefikcjonalne i nieliterackie. Taka sugestia, po pierwsze, wynika $\mathrm{z}$ atrakcyjności i przystępności tego rodzaju literatury, po drugie, jest rezultatem jej aktualnego znaczenia w kulturze literackiej, po trzecie, umożliwia poruszenie znacznie większego zakresu problematyki, po czwarte, jest spowodowana przekonaniem, że utwory niefikcjonalne nieraz lepiej oddają Stimmung współczesności.

Kwestia większej przystępności literatury niefikcjonalnej zwraca uwagę na znaczenie poetyki utworów dla ich oddziaływania i doboru w edukacji literackiej ${ }^{62}$. Oprócz aktualności tekstów niefikcjonalnych i przesunięcia w ich stronę

${ }^{58}$ Warto także rozwijać ten performatywny wymiar edukacji polonistycznej w innych obszarach, na przykład w edukacji teatralnej (zob. M. Pieniążek: Polonistyka performatywna. O humanistycznych technologiach wytwarzania światów. Towarzystwo Autorów i Wydawców Prac Naukowych „Universitas”, Kraków 2018, szczególnie s. 257 i nast.).

${ }^{59}$ H.U. Gumbrecht: Po roku 1945 ..., s. 46. Ujęcie Gumbrechta w nieco innym kontekście „czytania nastrojów” - przywoływał też Szczukowski (Praktykowanie lektury..., s. 49-50).

${ }^{60}$ Oczywiście dawne teksty również mogą na nas oddziaływać swoimi Stimmungen, „uobecniając przeszłość" (H.U. Gumbrecht: Po roku 1945..., s. 46).

${ }^{61}$ Tak Gumbrecht „,uobecnia przeszłość” w swoim najbardziej znanym dziele - In 1926, w którym przywołuje różne teksty kultury — od filozofii po modę i sport.

${ }^{62} \mathrm{To}$, rzecz jasna, obszerniejsze zagadnienie, nie dotyczące tylko polonistycznej odpowiedzi na wyzwania współczesności. Tutaj zasygnalizuję jedynie kilka kwestii, na które warto zwrócić uwagę przy doborze lektur. 
dominanty warto również szeroko wykorzystywać teksty pisane w pierwszej osobie. To indywidualne historie i personalne narracje najsilniej przemawiają do naszej wyobraźni, emocji i oddziałują na przekonania ${ }^{63}$.

Jak pisze Olga Tokarczuk:

Narrator pierwszoosobowy wprowadza zupełnie inną perspektywę — przesyconą emocjami, często ambiwalentnymi — i dodaje opowieści jakże potrzebnego i owocnego irracjonalizmu, paradoksu. Kochamy, a jednocześnie nienawidzimy. Czujemy się w tym momencie przyciągani i odrzucani. [...] To właśnie ta subiektywność sprawia, że świat przedstawiony nabiera złożonej faktury i wielowymiarowości ${ }^{64}$.

Dobrym przykładem siły pierwszoosobowej narracji może być książka Dość (2020) Doroty Sumińskiej, która w niezwykle sugestywny sposób apeluje o wrażliwość na krzywdę zwierząt. Oto przykład:

Jestem [...] krową mięsną. Mam tę samą duszę co krowa mleczna. Jestem tak samo społeczna i wesoła. Lubię towarzystwo przyjaciółek, rozmowy, gry i zabawy. Niestety ani ja, ani te, co dają mleko, nie możemy normalnie żyć, bo mamy bardzo ograniczony zakres ruchów. One z powodu ogromnych wymion i zamknięcia w malutkich boksach, a ja z powodu monstrualnej budowy. Pęka mi serce, gdy widzę, jak moje dziecko chce, a nie może podskoczyć, albo łamie nogę ${ }^{65}$.

Jak się wydaje, apel wygłoszony za pomocą dyskursywnego wywodu miałby znacznie mniejszą siłę oddziaływania niż ta pierwszoosobowa narracja, której autorka używa do zobrazowania różnych form cierpienia zwierząt.

W edukacji polonistycznej większą uwagę warto również poświęcić interpretacji fragmentów tekstów zamiast omawiania całych utworów ${ }^{66}$. Można

${ }^{63}$ Ma to również swoją negatywną stronę — bardziej ufamy jednostkowej historii niż ponadindywidualnej perspektywie, co czasem powoduje błędy poznawcze (zob. H. Rosling, O. Rosling, A. Rosling Rönnlund: Factfulness. Dlaczego świat jest lepszy niz myślimy, czyli Jak stereotypy zastapić realna wiedza. Tłum. M. Popławska. Media Rodzina, Poznań 2018, rozdział: Instynkt pojedynczej perspektywy).

${ }^{64}$ O. Tokarczuk: Czuly narrator..., s. 201-202 z 338. Tokarczuk także w swojej mowie noblowskiej przekonująco zwraca uwagę na rolę ,czułego narratora” w literaturze (O. Tokarczuk: Czuły narrator..., rozdział: Czuły narrator). Aczkolwiek wskazuje, że literatura i praca wyobraźni zaczynają się właśnie od wyjścia poza jednostkową perspektywę, myślę, że nie kwestionuje wagi narracji pierwszoosobowej, szczególnie na początku literackiej edukacji.

${ }^{65}$ D. Sumińska: Dość. O zwierzętach i ludziach, bólu, nadziei i śmierci. Wydawnictwo Literackie, Kraków 2020 [e-book, format epub], s. 19 z 139.

${ }^{66}$ Warunki pracy z fragmentem - co jest pożądaną w szkole praktyką — określa Zofia Agnieszka Kłakówna (Kulturowa koncepcja kształcenia polonistycznego. W: Polonistyka w przebudowie. Literaturoznawstwo - wiedza o języku - wiedza o kulturze - edukacja. Zjazd Poloni- 
dzięki temu pokazać więcej tematów, stanowisk, doświadczeń, perspektyw, zrealizować postulat dotyczący wielości i różnorodności.

\section{Jak uczyć, czyli o znaczeniu interpretacji raz jeszcze}

Warto powtórzyć apel: w centrum literackiej edukacji należy umieścić interpretację $^{67}$. Tu chciałbym zwrócić uwagę na trzy istotne, szczególnie ze względu na obecną sytuację i tendencje literaturoznawcze, kwestie: pluralizm interpretacji, pojmowanie interpretowania jako swoistego modus vivendi niezbędnego też jako podstawa funkcjonowania wspólnoty oraz różnicę między interpretacją a opinią.

Pedagogice pluralizmu sprzyja nie tylko wielość poetyk, gatunków i konwencji oraz kategorii estetycznych, które we właściwy sztuce sposób oddają wielość sposobów przeżywania rzeczywistości i patrzenia na nią, lecz także wywołująca podobny efekt polifonia metod ${ }^{68}$, dyscyplin i dyskursów. Różnorodność pod tym względem jest istotniejsza od krytyczno- czy historycznoliterackich hierarchii. Ów pluralizm powinien dotyczyć nie tylko metod filologicznych co wielokrotnie postulowano - ale przede wszystkim otwarcia na inne niż jedynie humanistyczne dyscypliny, perspektywy i dyskursy. Nie da się zrozumieć problemów współczesnego świata, na przykład dotyczących środowiska naturalnego, bez spojrzenia na nie z perspektywy różnych dziedzin — biologii, geografii, fizyki, chemii oraz bliższych filologii: psychologii, filozofii, socjologii, kulturoznawstwa, religioznawstwa, medioznawstwa. I choć takie wymagania wydają się utopijne, są już w szkole częściowo realizowane ze względu na „węzłowy" charakter języka polskiego jako przedmiotu.

Co ważniejsze jednak, interpretowanie należałoby pojmować jako modus vivendi — jako codzienny sposób bycia; zastosowanie interpretacji do literatury jest działaniem wtórnym, choć oczywiście rozwijającym kompetencje w tym zakresie. Naukę interpretacji warto zacząć od nauki odczytywania świata wokół nas — codziennych gestów i zachowań, wypowiedzi i napisów itp.

stów, Kraków, 22-25 września 2004. T. 2. Przewodn. zespołu red. M. Czermińska. Towarzystwo Autorów i Wydawców Prac Naukowych „Universitas”, Kraków 2005, s. 84).

${ }^{67}$ Nie trzeba uzasadniać tej filologicznej i dydaktycznej oczywistości, pomijam również rozważania na temat rodzajów interpretacji i ich aplikowalności w realiach szkolnych oraz dystynkcje między interpretowaniem a lekturą. Wypada jednak zaznaczyć, że skoro apele dotyczące konieczności skupienia się na interpretacji w szkole są stale ponawiane, oznacza to, że wciąż daleko do zrealizowania tego postulatu...

${ }^{68}$ Zob. krótki przegląd i propozycje aplikacji niektórych zwrotów współczesnej humanistyki w dydaktyce polonistycznej: K. Koziołek: Ziemia niczyja. Zwroty badawcze w literaturoznawstwie i ich konsekwencje dla nauczania literatury. „Postscriptum Polonistyczne” 2012, nr 2 (10), s. $109-126$. 
W postępowaniu z literaturą zaś należy odchodzić od perspektywy ergocentrycznej i formalistycznej - analitycznej ,pracy nad tekstem” — na rzecz traktowania utworów literackich jako narzędzi, środków, „portali” do rozumienia rzeczywistości i człowieka, czyli na rzecz ,pracy tekstem”, lub partnerów do konfrontacji z odmiennością, czyli „pracy z tekstem”69. Im bardziej bowiem pochylamy się nad walorami formalnymi tekstu, tym bardziej literaturę czynimy niedostępną, przede wszystkim dla tych, którzy chcieliby zacząć ją uprawiać.

Interpretowanie to jednak nie tylko sposób mówienia o literaturze i doświadczeniu człowieka oraz podstawa rozumienia świata i siebie ${ }^{70}$, lecz także warunek budowania wspólnoty w sytuacji wojen kulturowych, na co zwraca uwagę Michał Paweł Markowski. Jego zdaniem w dzisiejszym świecie nie uzgodnimy przekonań i nie będziemy dzielić wspólnych wartości, ale winniśmy zmierzać do porozumienia w sprawie celów, które musimy osiągać, żeby wspólnie żyć. By dojść do owego porozumienia, niezbędne są kompetencje pomagające w szukaniu wspólnego gruntu, wyciągania wniosków oraz uzgadniania działań. I do tego nieodzowna jest umiejętność interpretowania, której najlepiej uczy filologia.

Wreszcie interpretację należy odróżnić od wyrażania opinii; utożsamianie interpretacji i opinii jest powszechnym błędem ${ }^{71}$. O ile opinia jest wyrazem naszych odczuć czy wartości i nie szuka uzasadnienia u innych, o tyle interpretacja wymaga argumentów, dowodów pochodzących z tekstu ${ }^{72}$. Interpretowania trzeba jednak (na)uczyć, czego współczesna edukacja nie robi, pielęgnując raczej wyrażanie opinii. Inaczej mówiąc, należy przywrócić filologicznemu kształceniu należny mu status, bez tego bowiem nie będziemy w stanie się porozumieć i współdziałać we współczesnym świecie ${ }^{73}$.

Postawione w tym tekście diagnozy mogą wydać się zanadto dramatyczne, a propozycje być może grzeszą naiwnością. W dzisiejszych realiach — pod presją czasu, programów, ram formalnoprawnych, egzaminów, oczekiwań rodziców, uczniów i stosownych instytucji, ograniczeń kulturowych i mentalnych szanse na wdrożenie postulatów wydają się nikłe. Jestem jednak przekonany, że pandemia i narastające kryzysy zmuszają nas do ponownego namysłu nad kształtem edukacji i istotnej zmiany jej dominanty — rozważenia, czego, jak, a przede wszystkim po co uczyć. I nie możemy sobie pozwolić na zwłokę.

${ }^{69}$ R. Nycz: Kultura jako czasownik. Sondowanie nowej humanistyki. Instytut Badań Literackich PAN. Wydawnictwo, Warszawa 2017, s. 174 i nast.

70 Tak krótko i trafnie podsumowuje znaczenie interpretacji, nie tylko w szkole, Ewa Jaskóła (Dlaczego warto uczyć interpretacji? „Postscriptum Polonistyczne” 2012, nr 2 (10), s. 136, s. 127-136).

71 M.P. Markowski: Wojny nowoczesnych plemion..., s. 383.

72 Ibidem, s. 31.

73 Ibidem, s. 14 i nast. 


\section{Bibliografia}

Applebaum A.: Zmierzch demokracji. Zwodniczy powab autorytaryzmu. Przeł. P. Tarczyński. Wydawnictwo Agora, Warszawa 2020 [e-book, format epub].

Bendyk E.: W Polsce, czyli wszędzie. Rzecz o upadku i przyszłości świata. Polityka, Warszawa 2020 [e-book, format epub].

Biszewska J.: Polonistka: Zdalnie to możemy sobie porozmawiać przez telefon, ale nie uczyć. [Rozmowa z Małgorzatą Próchniak]. Edziecko, 4.03.2021. https://www.edziecko.pl/Juni or/7,160035,26826742,polonistka-zdalnie-to-mozemy-sobie-porozmawiac-przez-telefon. html\#s=BoxMMt3 [dostęp: 4.03.2021].

Borodaj D.: „Zachodzę pod dom ucznia, proszę, żeby stanąt w oknie, pomacham, pożartuję przez plot. Tyle moge”. Weekend.gazeta.pl, 4.02.2021. https://weekend.gazeta.pl/weekend/7,17733 4,26756212,zachodze-pod-dom-ucznia-prosze-zeby-stanal-w-oknie-pomacham.html [dostęp: 19.04.2021]

Borucka A., Pisarska A.: Koncepcja resilience — czyli jak pomóc dzieciom i młodzieży z grup podwyższonego ryzyka. Ośrodek Rozwoju Edukacji. Pobrano z: https://bezpiecznaszkola.men.gov. pl/projekty/Borucka_Pisarska.pdf [27.09.2021].

Bourdieu P., Passeron J.C.: Reprodukcja. Elementy teorii systemu nauczania. Przeł. E. Neyman. Wyd. 2. Wydawnictwo Naukowe PWN, Warszawa 2006.

Buchner A., Wierzbicka M.: Edukacja zdalna w czasie pandemii. Raport. Edycja II. Listopad 2020. Pobrano z: https://centrumcyfrowe.pl/wp-content/uploads/sites/16/2020/11/Raport Edukacjazdalna-w-czasie-pandemii.-Edycja-II.pdf [19.04.2021].

Długosz P.: Pokolenie przegranych? Kondycja psychospołeczna młodzieży w Europie Środkowo-Wschodniej. „Zeszyty Pracy Socjalnej” 2016, T. 21, nr 2, s. 77—90. https://doi.org/10.4467/24 496138PS.16.006.6276.

Domańska E.: Historia ratownicza. „Teksty Drugie” 2014, nr 5, s. 12-26.

Graeber D.: Praca bez sensu. Teoria. Przeł. M. Denderski. Wydawnictwo Krytyki Politycznej, Warszawa 2019.

Gumbrecht H.U.: Po roku 1945. Latencja jako źródło wspótczesności. Tłum. A. Paszkowska. Wstęp A. Krzemiński. Wydawnictwo Krytyki Politycznej, Warszawa 2016.

Guszta J.: Przewodnik po ksiązkach ekologicznych dla dzieci. „Znak” 2021, nr 4 (791), s. 32-33.

Hadot P.: Filozofia jako ćwiczenie duchowe. Przeł. P. Domański. Wydawnictwo Instytutu Filozofii i Socjologii PAN, Warszawa 1992.

Harari Y.N.: 21 lekcji na XXI wiek. Przeł. M. Romanek. Wydawnictwo Literackie, Kraków 2018 [e-book, format epub].

Irvine W.B.: Wyzwanie stoika. Jak dzięki filozofii odnaleźć w sobie siłę, spokój i odporność psychiczna. Przekł. O. Siara. Insignis, Kraków 2020.

Janion M.: Humanistyka. Poznanie i terapia. Państwowy Instytut Wydawniczy, Warszawa 1974.

Janus-Sitarz A.: Humanistyka w poszukiwaniu zaginionego czytelnika. W: Edukacja polonistyczna jako zobowiazanie. Powszechność i elitarność polonistyki. Red. nauk. E. Jaskółowa et al. T. 1. Wydawnictwo Uniwersytetu Śląskiego, Katowice 2016, s. 55-65.

Jarzyna A.: O czym myślę, kiedy myślę o zwierzętach w edukacji polonistycznej? Siedem odpowiedzi. „Polonistyka. Innowacje” 2020, nr 11, s. 63-76. https://doi.org/10.14746/pi.2020.11.6.

Jaskóła E.: Dlaczego warto uczyć interpretacji? „Postscriptum Polonistyczne” 2012, nr 2 (10), s. $127-136$.

Kahneman D.: Pułapki myślenia. O myśleniu szybkim i wolnym. Tłum. P. Szymczak. Media Rodzina, Poznań 2012. 
Kalita A.: 10-letnie dziecko mówi: „Mamy kredyt. Boję się, co będzie, jak rodzice straca pracę”. [Rozmowa z Justyną Britmann]. Weekend.gazeta.pl, 19.01.2021. https://weekend.gazeta.pl/ weekend/1,177333,26698880,10-letnie-dziecko-mowi-mamy-kredyt-boje-sie-co-bedzie-jak. html [dostęp: 30.01.2021].

Kłakówna Z.A.: Kulturowa koncepcja kształcenia polonistycznego. W: Polonistyka w przebudowie. Literaturoznawstwo - wiedza o języku - wiedza o kulturze - edukacja. Zjazd Polonistów Kraków, 22-25 września 2004. T. 2. Przewodn. zespołu red. M. Czermińska. Towarzystwo Autorów i Wydawców Prac Naukowych „Universitas”, Kraków 2005, s. 74-84.

Koc K.: Lekcje myślenia (obywatelskiego). Edukacja polonistyczna wobec wspótczesnego świata. Wydawnictwo Naukowe Uniwersytetu im. Adama Mickiewicza, Poznań 2018.

Koc K.: Software $w$ szkolnym kształceniu polonistycznym, czyli o znaczeniu aktualizacji teorii dydaktycznych. „Polonistyka. Innowacje” 2018, nr 7, s. 71—83. https://doi.org/10.14746/ pi.2018.1.7.6.

Koc K.: Wspótczesność ,,źle obecna” w szkole podstawowej, czyli o kryzysie edukacji humanistycznej. „Annales Universitatis Paedagogicae Cracoviensis. Studia ad Didacticam Litterarum Polonarum et Linguage Polonae Partinentia" 2019, s. 124 - 133. https://doi.org/10.24917/20820909.10.12.

Kopciewicz L.: Podręczniki szkolne jako narzędzie przemocy symbolicznej. W: Gender w podręcznikach. Projekt badawczy, raport. T. 1: O projekcie, metodologia badań, wprowadzenie teoretyczne. Red. I. Chmura-Rutkowska et al. Fundacja Feminoteka, Warszawa 2016. Pobrano z: https://repozytorium.amu.edu.pl/bitstream/10593/23643/1/Gender-w-podr\%C4\%99cznikach.Raport-Tom-1.pdf [15.07.2021], s. 81-92.

Kossowska M. et al.: Człowiek w obliczu pandemii. Psychologiczne i społeczne uwarunkowania zachowań w warunkach kryzysu zdrowotnego. Smak Słowa, Sopot 2020.

Koziołek K.: Czas lektury. Wydawnictwo Uniwersytetu Śląskiego, Katowice 2017.

Koziołek K.: Ziemia niczyja. Zwroty badawcze w literaturoznawstwie i ich konsekwencje dla nauczania literatury. „Postscriptum Polonistyczne” 2012, nr 2 (10), s. 109-126.

Koziołek R.: Bierność polityczna chłopów. W: Idem: Wiele tytułów. Wydawnictwo Czarne, Wołowiec 2019 [e-book, format epub], s. 207-253 z 439.

Krastew I.: Nadeszło jutro. Jak pandemia zmienia Europę. Przeł. M. Sutowski. Wydawnictwo Krytyki Politycznej, Warszawa 2020.

Leder A.: Prześniona rewolucja. Ćwiczenie z logiki historycznej. Wydawnictwo Krytyki Politycznej, Warszawa 2014.

Markowski M.P.: Polityka wrażliwości. Wprowadzenie do humanistyki. Universitas, Kraków 2013.

Markowski M.P.: Wojny nowoczesnych plemion. Spór o rzeczywistość w epoce populizmu. Wydawnictwo Karakter, Kraków 2019 [e-book, format epub].

Marquard O.: Opóźniona moralistyka. Uwagi o nieodzowności humanistyki. W: Idem: Szczesście w nieszczęściu. Rozważania filozoficzne. Przeł. K. Krzemieniowa. Oficyna Naukowa, Warszawa 2001, s. 108-115.

Michel M.: Wzmacnianie czynników chroniacych $w$ tworzeniu bezpiecznej przestrzeni szkoty w programach liderów rówieśniczych $w$ kontekście koncepcji resilience. „Resocjalizacja Polska / Polish Journal of Social Rehabilitation" 2014, [nr] 6, s. 101-120.

Myrdzik B.: Wielokulturowa Europa jako wyzwanie edukacyjne. W: Eadem: Zrozumieć siebie $i$ świat. Studia i szkice o edukacji polonistycznej. Wydawnictwo Uniwersytetu Marii Curie-Skłodowskiej, Lublin 2006, s. 393- 417.

Nancy J.L.: Arcyludzki wirus. Przekł. A. Dwulit. Wydawnictwo Ostrogi, Kraków 2021.

Nowak E.: Cele edukacji polonistycznej. W: Polonista w szkole. Podstawy ksztatcenia nauczyciela polonisty. Red. A. Janus-Sitarz. Universitas, Kraków 2004, s. 15-26.

Nussbaum M.C.: Nie dla zysku. Dlaczego demokracja potrzebuje humanistów. Przeł. Ł. Pawłowski. Przedmowa J. Kuisz. Fundacja Kultura Liberalna, Warszawa 2016. 
Nycz R.: Kultura jako czasownik. Sondowanie nowej humanistyki. Instytut Badań Literackich PAN. Wydawnictwo, Warszawa 2017.

Ochwat M.: Klimat — konflikty - migracje. Scenariusze przyszłości. „Postscriptum Polonistyczne” 2019, nr 2 (24), s. 51-71. https://doi.org/10.31261/PS_P.2019.24.04.

Ochwat M.: (Wspót)myślenie w humanistyce. Literackie ekokształcenie w epoce antropocenu. „Рolonistyka. Innowacje” 2020, nr 12, s. 31—51. https://doi.org/10.14746/pi.2020.12.3.

Pieniążek M.: Polonistyka performatywna. O humanistycznych technologiach wytwarzania światów. Towarzystwo Autorów i Wydawców Prac Naukowych „Universitas”, Kraków 2018.

Rąbkowska E.: Zwierzęta i ich dzieci - poznanie, empatia, etyka. Perspektywa ekokrytyczna w literaturze dla dzieci i młodzieży. W: P. Czapliński, J.B. Bednarek, D. Gostyński: Literatura i jej natury. Przewodnik ekokrytyczny dla nauczycieli i uczniów szkót średnich. Wydawnictwo Rys, Poznań 2017 [e-book, format epub], s. 67-93 z 428.

Rosling H., Rosling O., Rosling Rönnlund A.: Factfulness. Dlaczego świat jest lepszy, niż myślimy, czyli Jak stereotypy zastapić realna wiedza. Tłum. M. Popławska. Media Rodzina, Poznań 2018.

Sadura P.: Państwo, szkoła, klasy. Wydawnictwo Krytyki Politycznej, Warszawa 2018 [e-book, format epub].

Sikora A.: Wolność, równość, przemoc. Czego nie chcemy sobie powiedzieć. Wydawnictwo Karakter, Kraków 2019.

Sloterdijk P.: Musisz życie swe odmienić. O antropotechnice. Przekł. J. Janiszewski. Słowo wstępne A. Żychliński. Wydawnictwo Naukowe PWN, Warszawa 2014 [e-book, format epub].

Sławiński J.: Literatura w szkole: dziś i jutro. W: Idem: Teksty i teksty. Universitas, Kraków 2000, s. $82-101$.

Smulczyk M.: „Resilience” a edukacja. Rola fenomenu skutecznej adaptacji w osiagnięciach szkolnych. „Forum Oświatowe” 2016, [nr] 28 (2), s. 203-222.

Solnit R.: Nadzieja w mroku. Nieznane opowieści, niebywałe możliwości. Przeł. A. Dierzgowska, S. Królak. Wydawnictwo Karakter, Kraków 2019.

Spitzer M.: Cyfrowa demencja. W jaki sposób pozbawiamy rozumu siebie i swoje dzieci. Przeł. A. Lipiński. Wydawnictwo Dobra Literatura, Słupsk 2013.

Stankiewicz P.: Sztuka życia wedtug stoików. Grupa Wydawnicza Foksal - Wydawnictwo WAB, Warszawa 2014.

Stanowisko 10. zespolu ds. COVID-19 przy Prezesie PAN: Konsekwencje pandemii COVID-19 dla zdrowia psychicznego i edukacji dzieci i młodzieży. Polska Akademia Nauk, 25.01.2021. https:// informacje.pan.pl/index.php/informacje/materialy-dla-prasy/3233-stanowisko-10-zespolu-ds -covid-19-przy-prezesie-pan-konsekwencje-pandemii-covid-19-dla-zdrowia-psychicznego-iedukacji-dzieci-i-mlodziezy [dostęp: 19.04.2021].

Stiegler B.: Wstrzasy. Gtupota i wiedza w XXI wieku. Przekł. M. Krzykawski. Wydawnictwo Naukowe PWN, Warszawa 2017 [e-book, format epub].

Sumińska D.: Dość. O zwierzętach i ludziach, bólu, nadziei i śmierci. Wydawnictwo Literackie, Kraków 2020 [e-book, format epub].

Szczukowski D.: Praktykowanie lektury. Wydawnictwo Uniwersytetu Gdańskiego, Gdańsk 2019.

Taibbi M.: Nienawiść sp. z o.o. Jak wspótczesne media każq nam gardzić sobq nawzajem. Przeł. T.S. Gałązka. Wydawnictwo Czarne, Wołowiec 2020 [e-book, format epub].

Taleb N.N.: Antykruchość. Jak żyć w świecie, którego nie rozumiemy. Przeł. O. Siara. Zysk i S-ka Wydawnictwo, Poznań 2020 [e-book, format epub].

Taleb N.N.: Czarny łabędź. Jak nieprzewidywalne zdarzenia rządza naszym życiem. Przeł. O. Siara. Zysk i S-ka Wydawnictwo, Poznań 2020 [e-book, format epub].

Tokarczuk O.: Czuły narrator. Wydawnictwo Literackie, Kraków 2020 [e-book, format epub].

Tomaszewska G.B.: Praktyki czytania. Ponowoczesna interpretacja a szkoła. Wydawnictwo Uniwersytetu Gdańskiego, Gdańsk 2019. 
W stronę nowej podstawy programowej języka polskiego. [Dyskusja panelowa online]. Organizator: Centrum Badań Edukacyjnych i Kształcenia Ustawicznego na Wydziale Polonistyki Uniwersytetu Jagiellońskiego. MS Teams, 19.04.2021.

Zuboff S.: Wiek kapitalizmu inwigilacji. Walka o przyszłość ludzkości na nowej granicy władzy. Tłum. A. Unterschuetz. Zysk i S-ka Wydawnictwo, Poznań 2020 [e-book, format epub].

Žižek S.: Pandemia! COVID-19 trzęsie światem. Przekł. J. Maksymowicz-Hamann. Wydawnictwo Relacja, Warszawa 2020 [e-book, format epub]. 